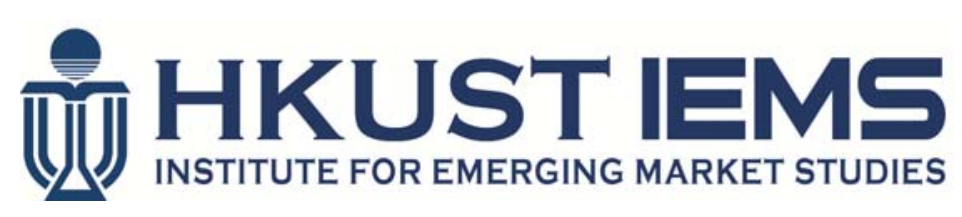

\title{
Benefiting from Disaster?: Public and Private Responses to the Wenchuan Earthquake
}

\author{
Albert PARK, Sangui WANG
}

HKUST IEMS Working Paper No. 2015-36

June 2016

HKUST IEMS working papers are distributed for discussion and comment purposes. The views expressed in these papers are those of the authors and do not necessarily represent the views of HKUST IEMS.

More HKUST IEMS working papers are available at: http://iems.ust.hk/WP 


\title{
Benefiting from Disaster?: Public and Private Responses to the Wenchuan Earthquake
}

Albert PARK, Sangui WANG

HKUST IEMS Working Paper No. 2015-36

June 2016

\begin{abstract}
We provide the first household survey-based evidence on the impact of the 2008 Wenchuan earthquake on the welfare of rural households. Asset and income losses were substantial, especially in seriously affected areas. Our main finding is that there was an overwhelming government response to the disaster. Subsidies provided to households in 2008 were so large that mean income per capita was 17.5\% higher in 2008 than in 2007 and the poverty rate actually declined from $34 \%$ to $19 \%$. Using distance from the epicenter as an instrument for earthquake damage, we find a strong positive statistical relationship between lost value of housing and other assets due to the earthquake and increases in income per capita and government transfers received, and much weaker responsiveness of private transfers, wage labor supply, and borrowing.
\end{abstract}

\section{Authors' contact information}

\author{
Albert Park \\ Division of Social Science, Department of Economics \\ Hong Kong University of Science and Technology \\ E: albertpark@ust.hk \\ Click here to enter text. \\ Sangui Wang \\ Department of Economics \\ Remin University of China
}




\title{
Benefiting from Disaster?: Public and Private Responses to the Wenchuan Earthquake*
}

\author{
Albert Park, HKUST \\ Sangui Wang, Renmin University of China
}

February 2016

\begin{abstract}
We provide the first household survey-based evidence on the impact of the 2008 Wenchuan earthquake on the welfare of rural households. Asset and income losses were substantial, especially in seriously affected areas. Our main finding is that there was an overwhelming government response to the disaster. Subsidies provided to households in 2008 were so large that mean income per capita was $17.5 \%$ higher in 2008 than in 2007 and the poverty rate actually declined from $34 \%$ to $19 \%$. Using distance from the epicenter as an instrument for earthquake damage, we find a strong positive statistical relationship between lost value of housing and other assets due to the earthquake and increases in income per capita and government transfers received, and much weaker responsiveness of private transfers, wage labor supply, and borrowing.
\end{abstract}

*The authors acknowledge financial support for the survey from China's Leading Group Office for Poverty Alleviation, as well as the helpful comments of the editors and an anonymous referee. 


\section{Introduction}

On May 12, 2008, an earthquake registering 8.0 on the Richter scale struck western China. According to official statistics, 69,200 people were killed, 17,900 went missing, 374,643 were injured, and the value of damage was estimated to be 845 billion RMB (about 121 billion US dollars). The epicenter was in Wenchuan County, which is located in a poor, mountainous region of Sichuan Province.

China was widely praised for its rapid and massive government-led response to the disaster (Shie et al, 2012). The government quickly mobilized the People's Liberation Army to assist in recovery and relief efforts, and provided subsidies, temporary shelter, food rations, and other supplies to earthquake victims. In early 2009, in response to the global economic crisis the government passed a massive 4 trillion RMB stimulus package, of which $25 \%$ (or 1 trillion RMB) went to earthquake reconstruction. In addition, richer provinces were paired with disaster-affected counties and required to put aside $1 \%$ of provincial government revenue to assist in the reconstruction work in partner counties, a massive amount of funds relative to the ordinary budgets of those counties. By the end of September 2009, China also had mobilized 79.7 billion RMB in social contributions from individuals and NGOs inside and outside of China.

Although many of these facts about China's response to the Wenchuan earthquake have been well-documented, to date no systematic evidence has been provided on how the earthquake affected individual households in disaster-affected areas. Because the earthquake occurred in a very poor region, there is particular concern that poor households were ill-equipped to cope with such a traumatic shock. 
The goal of this paper is to provide the first household survey-based evaluation of the impacts of the earthquake, as well as subsequent public and private responses to the disaster, on the welfare of rural households. We accomplish this goal by analyzing data from a unique survey of households living in poor villages in earthquake-affected regions that was conducted 10 months after the earthquake which asked detailed questions about household income and assets before and after the earthquake, as well as about changes in wage labor supply, government transfers, private transfers, and borrowing. We first present descriptive evidence on the extent of earthquake damage and changes in income (including government and private transfers), poverty, borrowing, and labor supply. We then conduct regression analysis to examine how pre-transfer income, income (including transfers), wage labor supply, government transfers, private transfers, and borrowing were affected by the value of losses due to earthquake damage. To address the potential endogeneity of earthquake damage, we use distance from the earthquake epicenter (defined by earthquake damage zone dummy variables) as an instrument for the $\log$ of the value of housing and other assets lost due to the earthquake.

We find that government assistance in 2008 , the year of the earthquake, was so substantial that despite significant negative shocks to pre-transfer income caused by the earthquake, mean income per capita including transfers rose and poverty rates fell by $14 \%$ (from $32 \%$ to $18 \%$ ) compared to 2007 . Without public and private transfers, the poverty rate would have been $39 \%$ in 2008 . The regression analysis confirms a strong positive statistical relationship between earthquake damage and increases in 
income per capita and government transfers received, and much weaker responsiveness of private transfers, wage labor supply, and borrowing.

This paper contributes to a large literature on risk-coping in developing countries (see, for example, Morduch, 1995; Dercon, 2002) and a much smaller literature on the impact of natural disasters on household welfare (Sawada, 2007). Aggregate economic shocks like disasters often are difficult for households to cope with because community members cannot provide sufficient assistance to each other when everyone has been adversely affected. Disasters such as earthquakes also differ from typical income shocks associated with drought or floods because they destroy household assets (especially housing) which can lead to much larger permanent income shocks that may have longer, more persistent impacts on household consumption levels.

Two of the only rigorous microeconomic studies of household impacts of a natural disaster are by Sawada and Shimizutani $(2007,2008)$. They found that after the Kobe earthquake, the ability of households to smooth consumption was highly imperfect (Sawada and Shimizutani, 2007). In fact, the most important form of risk coping was reducing consumption (25.0\%), followed by borrowing (9.4\%). Private transfers were the most commonly used risk-coping mechanism (over 50\%). Only $20.4 \%$ of surveyed households reported that public transfers helped them to cope with the negative shock, and only $7.4 \%$ said it was the most important risk-coping mechanism (Sawada and Shimizutani, 2008). One limitation of these studies is that they are based entirely on subjective reports of risk-coping mechanisms used, with no 
direct measurements of income or consumption.

A World Bank study of poverty in Aceh (Indonesia) found that the poverty headcount rate increased from $28.4 \%$ before the tsunami to $32.6 \%$ in the year after the tsunami. Households living in high tsunami areas were $17 \%$ less likely to be poor before the tsunami (after controlling for age, gender, education, occupation, and household size) but were $44 \%$ more likely to be poor the year after the tsunami. Receiving government aid and NGO aid increased the chance of escaping poverty by $43 \%$ and $23 \%$ (World Bank, 2008). The US government's response to Hurricane Katrina was criticized for being slow in the emergency relief period, and the planning process for reconstruction efforts also was delayed; one result was a massive outmigration of the population, many of whom have not returned (Kates et al., 2006). The Turkish government also was criticized for its poor response to a major earthquake in 1999 (Jacoby, 2008).

\section{Data}

We draw upon data from a unique survey of 3000 rural households living in 100 poor villages in ten counties in disaster-affected areas that was conducted less than a year after the earthquake occurred. The survey was conducted in late February 2009 just more than 10 months after the earthquake. The sampling method was designed to ensure the household sample was representative of households living in poor villages in earthquake-affected areas. The ten counties were randomly drawn from the 51 earthquake-affected counties in Sichuan, Gansu, and Shaanxi Provinces using an 
interval sampling method using county population as weights. Six counties in Sichuan, three counties in Gansu and one county in Shaanxi were selected. Of the ten surveyed counties, three (all in Sichuan) were classified as being seriously affected by the disaster. Within each sample county, ten villages were randomly selected from the list of nationally designated poor villages in the county using the same method. Poor village designations are based on multiple criteria determined by county and provincial governments, and qualify villages for targeted public investments for poverty alleviation financed by the central government (Park and Wang, 2011).

Within each village, 30 household were randomly sampled. Village leaders first ranked all households in the village by economic status and then households were selected using a random starting point and fixed interval. In cases of nonresponse, households were replaced with the household nearest to them on the list (just above then just below) with this process being repeated as necessary. The survey was supervised by one of the authors with the support of national, provincial, and county government Leading Group Offices for Poverty Alleviation and Development (LGOPAD). University students from Sichuan and Gansu served as enumerators.

The survey asked retrospective questions about the household's economic conditions before and after the earthquake (in 2007 and 2008) including detailed information on income transfers from various sources. It also asked direct questions about the value of damage suffered due to the earthquake. This enables an analysis of how the earthquake and subsequent responses affected the well-being of rural households. We control for inflation by deflating all 2008 nominal values using 
provincial rural CPIs. A village community questionnaire was also completed based on interviews with village leaders. Means and standard deviations of all variables used in the analysis are provided in the Appendix.

\section{Descriptive evidence}

In this section, we present descriptive evidence on the extent of damage to property caused by the earthquake, the impact of the earthquake on incomes and poverty, the magnitude of public and private transfers as well as household borrowing, and labor responses to the earthquake. In each case, we report summary statistics for the whole sample and separately for households in seriously affected areas and in less affected areas. These categories are based on official criteria used to determine the eligibility of counties to receive different levels of assistance.

Table 1 presents summary information on the extent of property losses suffered by households. Property is divided into three types: cultivated land, housing, and non-housing assets (including consumer durables and fixed assets for production). For the full sample, $9.0 \%$ of households suffered damage to cultivated land, $46.4 \%$ suffered serious damage to housing, $97.6 \%$ suffered at least some damage to housing, and $38.5 \%$ suffered damage to other assets. Thus, nearly all households suffered from some damage to their property $(98.1 \%)$. The share of households experiencing different types of damage was significantly greater in seriously affected areas; for example the share of households suffering from land losses, serious damage to housing, and damage to other assets was $38.1 \%, 71.7 \%$, and $79.1 \%$ in seriously affected areas but only $3.9 \%, 35.5 \%$, and $26.6 \%$ in less affected areas.

In terms of the value of property lost, by far the most important category was housing. This is not surprising given that housing accounts for a very high share of 
total household wealth in rural areas. On average, the value of lost housing value per capita was over 4000 yuan, and in seriously affected areas it was 8737 yuan. Damage to other assets on average was small by comparison-just less than 400 yuan overall and 1143 yuan in seriously affected areas. Overall, the proportion of pre-earthquake assets (housing plus other assets) lost due to earthquake was $42.5 \%$ overall, $62.0 \%$ in seriously affected areas, and $26.6 \%$ in less affected areas. Thus, for many households the earthquake destroyed most of their existing property. Average asset losses were equal to about 1.6 years of average household income.

How did the earthquake affect incomes per capita? To get at this question, we compare household incomes in 2008 and 2007 based on retrospective questions on income included in the household questionnaire. Results are reported in Table 2. Given that the earthquake didn't occur until May of 2008, comparing incomes in the two years could lead to underestimation of the impacts of the earthquake since there was presumably no disruption from January to the time of the earthquake in May 2008. However, since the earthquake occurred before the main summer harvest, the income differences should accurately reflect shocks to agricultural cropping income. Also, rural China has experienced steady income growth over time, which means that a simple change in income from 2007 to 2008 may underestimate negative income effects if absent the earthquake 2008 incomes would have been higher than 2007 incomes.

It is helpful to distinguish between income per capita (including transfers) and pre-transfer income per capita (which excludes transfers). The difference between these two measures is the net transfers per capita received by the households, which can be divided into three parts: government transfers, private transfers (from relatives and friends), and other transfers (from NGOs, other social organizations, or other 
sources). Government transfers include both subsidies for agricultural production and consumption subsidies. In $2007,89 \%$ of government transfers were production subsidies, and in 2008 prior to the earthquake in May, 78\% of government transfers were production subsidies. However, after the earthquake nearly $100 \%$ of government transfers were for consumption.

To see how the earthquake affected earned income, we look at changes in pre-transfer income per capita from 2007 to 2008. Mean pre-transfer income per capita was 2926 yuan in 2007 and fell to 2332 in 2008, a decline of 20.3\% (Table 2). The decline in mean pre-transfer income per capita was $36.1 \%$ in seriously affected areas and $13.6 \%$ in less-affected areas. Mean pre-transfer income per capita in 2007 was similar in seriously and less affected areas, suggesting that exposure to earthquake damage was not strongly correlated with regional income levels.

How did households cope with large income shortfalls caused by the earthquake? Perhaps the most remarkable finding from the survey data is that government assistance was so substantial that on average it more than compensated households for the negative shocks to income. The average (pre-transfer) income loss per capita was 594 yuan, while the average increase in government transfers from 2007 to 2008 was 806 yuan (Table 2). In 2008, mean government transfers per capita (1024 yuan) were equal to $43.9 \%$ of household pre-transfer income per capita. Increases in government transfers per capita from 2007 to 2008 were much greater in seriously affected areas (1596 yuan) than in less affected areas (627 yuan) (Table 2). These benefits were spread widely, with over $99 \%$ of households reporting receiving government transfers in 2008 (Table 2).

In comparison to public transfers, private transfers were much less important. On average net private transfers per capita received increased from -195 yuan in 2007 to 
-27 yuan in 2008. Thus, even after the earthquake, mean net private transfers were negative, although there was heterogeneity across regions. In 2008, the average amount of transfers per capita received was positive in seriously affected areas (306 yuan) and negative in less affected areas (-165 yuan); there was almost no difference in 2007.The share of households receiving positive net transfers increased modestly; $12.5 \%$ of households received positive net transfers in 2007 compared to $17.2 \%$ in 2008 (Table 2).

Transfers from non-government, non-private sources were minimal, with only $9.1 \%$ of households reporting receiving such transfers and the average amount of other transfers per capita being only 16 yuan. This is consistent with the lack of involvement of international NGOs in China's earthquake relief efforts (Huang et al., 2011).

What was the net effect of negative income shocks caused by the earthquake and transfers received by households on the well-being of rural households living in poor villages? Remarkably, mean income per capita (including transfers) in 2008 was $17.5 \%$ greater than mean income per capita in 2007, even though pre-transfer income declined by $20.3 \%$. The increase in income per capita was greater in seriously affected areas $(36.4 \%)$ than in less affected areas $(9.5 \%)$. This increase in average income per capita was driven by large government subsidies. The extent of public support for the incomes of the poor after the Wenchuan earthquake contrasts strikingly with evidence of minimal support from government following the Kobe earthquake in Japan and the Katrina disaster in the US (Sawada and Shimizutani, 2008; Waugh, 2006; Kates et al, 2006).

Table 3 describes how poverty headcount measures were affected by negative income shocks and public and private transfers. In 2007, applying the government's 
official poverty line to data on household pre-transfer income per capita, the poverty headcount rate was $32 \%$; using income per capita (including transfers) the poverty rate was also $32 \%$ reflecting the fact that households were receivers of public transfers but net providers of private transfers. In 2008, the headcount poverty rate using pre-transfer income per capita as $39 \%$, or 7 percentage points greater than in 2007 , but the poverty rate using income per capita (including transfers) was only $18 \%$, or $14 \%$ less than the comparable poverty rate in 2007 . Comparing seriously affected areas with less affected areas, we find that using pre-transfer income the poverty rate was lower in seriously affected areas in 2007 but in 2008 it was 9\% higher; using income per capita (including transfers) the poverty headcount rate was actually lower in seriously affected areas (10\%) than in less affected areas (21\%) in 2008. Again this evidence suggests that households became relatively better off if they lived in areas hit harder by the earthquake.

We further investigate how well public transfers in 2008 (mostly following the earthquake) were targeted to those with greater need by calculating the share of public transfers provided to households in different 2008 pre-transfer income per capita deciles. As seen in Panel A of Figure 1, transfers are somewhat progressive, with those in poorer deciles receiving greater shares than those in richer deciles. However, many transfers were still received by better off households; while $14.7 \%$ of transfers went to the poorest decile $7.9 \%$ went to the richest. In Panel B of Figure 1, we present a similar figure ranking households by the value of assets lost in 2008 instead of by pre-transfer income per capita. Public transfers are more progressive with respect to asset loss than with respect to pre-transfer income; $17.5 \%$ of public transfers go to the decile with the greatest asset losses, compared to $5.1 \%$ to those with the fewest asset losses. 
Next we look at other ways in which households may have responded to the disaster. First, we examine how much money households borrowed after suffering negative income and wealth shocks. Such borrowing could help households rebuild their assets while maintaining desired consumption levels. However, the need for borrowing could have been reduced given the large government transfers. Second, we look at household labor supply decisions. Households hit by negative income shocks could respond by increasing labor supply in order to smooth household incomes (Fafchamps, 1993; Kochar, 1999). Local off-farm employment opportunities could be negatively affected by large disasters, since households might reduce spending given lower incomes and the need to rebuild assets, which would dampen local demand for goods and services. If this is the case, households could respond by migrating to more distant locations that were less adversely affected by the earthquake. On the other hand, once reconstruction activities begin, there could be an increased demand for construction workers which might raise local equilibrium wages and increase the attractiveness of working locally. Another reason rural residents may choose to stay home in the immediate aftermath of the earthquake is to ensure that they know about government relief policies and that they claim all of the government entitlements for which they are eligible.

In Table 4, we present evidence on household borrowing activity. Mean new borrowing per capita in 2008 (1590 yuan) was considerably greater than in 2007 (881 yuan), and most of the new borrowing in 2008 occurred after the earthquake (1363 yuan). The share of households with new borrowing in 2008 was also greater (40.2\%) than in 2007 (33.0\%). Borrowing per capita was greater in seriously affected areas (1027 yuan) than in less affected areas (821 yuan) in 2007 but the opposite was true in 2008. This means that the increase in new borrowing was greater in less affected areas, 
perhaps in response to less government support being provided than in seriously affected areas.

At the time of the earthquake, households reported an average ability to borrow 3522 yuan per capita. To put this in perspective, the average loss of housing value and other assets in 2008 compared to 2007 was 4492 yuan per capita and the average pre-transfer income loss was 594 yuan. These numbers suggest that households had sufficient access to credit to cope with the income shocks caused by the earthquake but not with the wealth shocks. Also it appears that many households did not borrow up to their self-reported credit limits, perhaps in part because of the substantial value of government transfers.

In Table 5, we present evidence on labor supply and wages. The main findings are that there was a decline in hours worked and wage income earned, and local wages declined slightly. Thus the labor market did not provide a means for households to make up for the income loss suffered due to the earthquake. The number of individuals participating in wage employment increased by $4.2 \%$ from 2007 to 2008, a rate that was similar in seriously affected areas and less affected areas. However, the number of months worked per worker declined by $15.3 \%$ overall, by $20.7 \%$ in seriously affected areas and by $13.1 \%$ in less affected areas. Wages per month also declined slightly, by $5.5 \%$. As a result, wage income per capita fell by $16.7 \%$ from 2007 to 2008 , and the share of wage income in total household income fell from $51.1 \%$ to $39.6 \%$. There was no significant change in the share of workers engaged in local wage employment and migration, and wage declines were similar for both types of employment. Thus, there was no outmigration response to the large disaster. This lack of outmigration contrasts with the large population movements observed following other major natural disasters, especially Hurricane Katrina in the US (Frey and Singer, 
2006) but also following the tsunami in Aceh (World Bank, 2008) and the Kobe earthquake (Horwich, 2000). In these other disaster episodes, more vulnerable populations were more likely to migrate (World Bank, 2008; Frey and Singer, 2006), however in Aceh the desire to gain access to relief provisions may have led many to return to disaster-affected areas (World Bank, 2008).

\section{Empirical analysis}

In this section, we empirically analyze the relationship between earthquake damage and different household-level outcomes using multivariate regression analysis. Our preferred specification compares outcomes before and after the earthquake, controls for a variety of household and county-level initial conditions, and uses distance from the earthquake epicenter as an instrument for earthquake damage while controlling for other geographic variables. We use the log of the value of housing and other assets lost due to the earthquake (in $1000 \mathrm{RMB}$ ) to measure earthquake damage. ${ }^{1}$

We examine how earthquake damage impacts a number of household-level outcomes. We first examine the reduced form relationship between earthquake damage and changes in both pre-transfer income per capita and income per capita (including transfers). We expect damage to negatively affect pre-transfer income per capita, although it is possible that damage to housing and durable assets does not

\footnotetext{
${ }^{1}$ As seen in Table 1, loss of land was much less common ( $9 \%$ of sample) compared to housing damage (98\%) and damage to other assets (39\%). Including a single damage indicator is desirable to avoid problems of collinearity across damage indicators and to focus on one endogenous regressor in the IV estimation. When including loss of land in OLS specifications, the coefficient was never statistically significant and did not greatly alter the coefficients on our preferred damage indicator.
} 
directly affect household production activities and that labor supply responses mitigate negative income effects. The extent to which damage negatively affects income per capita (net of transfers) depends on the extent to which public and private transfers counteract the negative shocks associated with the earthquake.

To better understand the risk-coping mechanisms used by households to respond to negative earthquake shocks, we examine four household responses: wage labor supply measured in person-months, government transfers received, net private transfers received, and new borrowing (after the earthquake). With respect to wage labor supply, on the one hand, the disaster could dampen demand for local goods and services and so depress wages and/or wage employment opportunities. On the other hand, the earthquake could be a push factor encouraging local residents to outmigrate in order to earn more income to help make up for lost income due to the disaster. In addition, reconstruction projects could boost local labor demand.

We expect both public and private transfers, as well as borrowing, to increase in response to negative income or wealth shocks caused by the earthquake. However, some endogeneity concerns could lead to bias in our coefficient estimates, for example if poorer households were more susceptible to earthquake damage due to the location or quality of their housing and also had weaker family or social networks to provide support in times of need. Also, it is possible that public transfers could crowd out private transfers. If public transfers were sufficiently generous, private transfers could even decline in response to earthquake damage! 
Our main regression specification for the empirical tests is the following equation:

$$
\Delta Y_{i c t}=D_{i c t} \beta+X_{i c t-1} \alpha+\gamma_{c}+\Delta e_{i c t}
$$

Changes in outcome $\mathrm{Y}_{\text {ict }}$ from before to after the earthquake of household $\mathrm{i}$ in county c is modeled as a function of earthquake damage $D_{\text {ict, }}$ a vector of household characteristics $X_{\text {ict-1 }}$ measured prior to the earthquake, county fixed effects $\gamma_{c}$, and an idiosyncratic error term $\Delta \mathrm{e}_{\mathrm{ict}}$. Since the dependent variables are measured in differences, the inclusion of county fixed effects controls for county-specific trends, and controlling for initial period household characteristics controls for additional variation in outcome changes that are correlated with initial household-level differences. These control variables, all measured in 2007 prior to the earthquake, include age of household head, household size, number of laborers, dummy for having no labor, share of labor who graduated from middle school, share of labor with high school degree or higher, cultivated land per capita, log of housing value per capita, and log of other asset value per capita.

To address the possible endogeneity of earthquake damage, we use a set of dummy variables corresponding to earthquake damage zones defined by geologists based on the distance of each village from the epicenter fault line of the earthquake. The boundaries of these zones are plotted in Figure 1. The seriously affected counties described earlier are nearly all in the two zones closest to the epicenter (Regions 8 and 9). To reduce possible bias from confounding location and geographic factors, we also include a set of geographic variables as controls in all regressions, including log of 
distance to nearest national (paved) road, distance to nearest river, distance to nearest rail station, and dummies for whether the village is in mountainous or hilly terrain. To fully exploit the power of using variation in distance from epicenter to explain earthquake damage, we drop county fixed effects when employing the IV strategy and instead control for key county-level variables including county population, county GDP per capita, and county budgetary revenue per capita, all measured before the earthquake (in 2007), as well as province fixed effects.

The first-stage regression results are reported in Appendix Table 4. They show as expected that compared to Region 5, asset damage increases for each region as one moves closer to the earthquake epicenter, and that these differences are statistically significant. The first stage F-statistic is 20.3 , so there is no weak instrument problem. We also tried using the $\log$ of distance to the epicenter as the instrument for asset damage, and found a very strong first stage and very similar results. ${ }^{2}$ We note that we cannot fully rule out that unobserved county or village trends are correlated with distance to the epicenter, however such trends would have to be uncorrelated with the large set of pre-earthquake household, county, and geographic variables that are controlled for in the regressions.

For each dependent variable, we report coefficient estimates for three specifications: OLS with county fixed effects, OLS with province fixed effects

\footnotetext{
2 These results are not reported but available from the authors. The only notable difference was that the IV results for new borrowing showed a marginally significant (at 10\% level) negative response to earthquake damage, compared to a negative and statistically insignificant effect using earthquake regions as the IVs. This provides suggestive evidence that large government transfers reduced the need for borrowing. All other coefficient magnitudes were very similar and had the same statistical significance.
} 
controlling for county-level variables, and the same specification employing instrumental variables. In all specifications, we cluster standard errors by village, the same level of precision as the instruments. We also note none of the results are sensitive to the inclusion or exclusion of outliers.

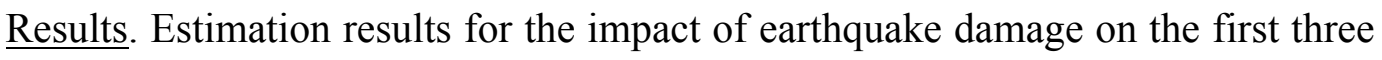
outcome variables are reported in Table 6 , and those for the last three outcomes are reported in Table $7 .^{3}$ As seen in columns 1 and 2 of Table 6 , the coefficients on the damage variable in all three specifications are negative as expected and of similar magnitude (although not statistically significant for the IV regression). A 100 percent change in asset damage reduces income per capita by 146 to $175 \mathrm{RMB}$.

For income per capita including transfers, the damage variable has a positive but statistically insignificant coefficient for both OLS specifications (columns 3 and 4 of Table 6). The coefficient for the IV estimation is significantly positive, the point estimate suggesting that a 100 percent increase in asset losses increases income per capita by $1,347 \mathrm{RMB}$.

The OLS estimates find that labor supply falls with greater asset losses due to the earthquake, consistent with there being negative labor demand shocks associated with the earthquake or a desire for individuals to stay at home to make sure they claim benefits to which they are entitled (columns 5 and 6 of Table 6). However, the

\footnotetext{
${ }^{3}$ The full set of OLS regression results are reported in Tables A2 and A3. The first-stage results for the IV estimation are presented in Table A4. The coefficients on the control variables in the IV estimations are nearly identical to the OLS results and are available from the authors upon request.
} 
coefficient on the log of the value of asset losses per capita is close to zero for the IV specification and not statistically significant in any of the OLS or IV specifications.

Next, we study the responsiveness of public transfers, private transfers, and new borrowing to earthquake damage. Results are reported in Table 7. We find that government transfers are highly responsive to most of the earthquake damage variables. For all three specifications, the coefficient on the damage variable is positive and highly statistical significant. The IV estimate is larger in magnitude than the OLS specifications, suggesting that villages with more damage may be disadvantaged in obtaining subsidies, for example due to poorer political connections, leading to downward bias in the OLS estimates. The magnitude of the IV estimate suggests that a 100 percent increase in asset losses increases government transfers by 889 RMB.

Next, we turn to private transfers. In contrast to the results for government transfers, none of the coefficients are statistically significant. The magnitude of the preferred IV estimate (434) is about half the magnitude of that of the public transfer regression. As for government transfers, the OLS estimates are smaller in magnitude than the IV estimates (and even slightly negative for the OLS specifications), suggesting that individuals with greater asset losses may be less able to mobilize transfers. For example, it could be the case that households with greater asset losses live in more fragile houses and are poorer, and also have poorer social networks that cannot provide as much support as those experiencing less earthquake damage. Thus, private and government transfers both respond positively to earthquake damage, but 
the response is larger and statistically significant only for government transfers. The lack of statistical significance of the responsiveness of private transfers to earthquake damage could also reflect large variation in the size and quality of social networks available to different households.

We also tested whether private transfers are crowded out by government transfers by including government transfers as a right-hand variable in the same regressions, and found the effect to be small and statistically insignificant. However, because government transfers are likely to be endogenous to unobserved household and community factors, we should not read too much into this result.

Finally, we examine the responsiveness of borrowing to earthquake damage. Our preferred IV specification finds that borrowing declines with greater earthquake damage, but the coefficient estimate is not statistically significant. This result contrasts with those from the OLS specifications, which show a statistically significant positive impact of earthquake damage on new borrowing. It could be the case that the positive responsiveness of government and private transfers reduces the need for households to borrow new funds. This may explain why the more positive IV estimates (compared to OLS) for government and private transfer responsiveness corresponds to a lower estimate of the responsiveness of new borrowing.

\section{Conclusions}

Viewed in comparative perspective, the extent of government support for victims of the Wenchuan earthquake was impressive and likely unprecedented. Whereas after 
most recent large natural disasters (e.g., tsunami in Aceh, Indonesia, Kobe earthquake), provision of government subsidies is very modest and incomes and consumption fall sharply while poverty increases, in China government support was so great that households on average were actually made better off and poverty rates fell during the year of the earthquake.

However, economists are often concerned that excessive aid can crowd out private sources of support, reducing the impacts of public transfers, and can also lead to dependency that reduces work incentives. Our empirical results suggest that government transfers were relatively well-targeted to those who suffered losses from earthquake damage. Our estimates suggest that private transfers were less responsive to earthquake damage, and this association is not statistically significant. And there is no evidence of outmigration or a positive wage labor supply in response to the earthquake. 


\section{References}

Dercon, Stefan. 2002. "Income Risk, Coping Strategies, and Safety Nets", World Bank Research Observer 17(2): 141-166.

Fafchamps, Marcel. 1993. "Sequential Labor Decisions Under Uncertainty: An Estimable Household Model of West-African Farmers," Econometrica 61(5): 1173-1197.

Frey, W.H., and A. Singer. 2006. Katrina and Rita Impacts on Gulf Coast Populations: First Census Findings (Washington, D.C.: Brookings Institution).

Horwich, George. 2000. "Economic Lessons of the Kobe Earthquake," Economic Development and Cultural Change 48(3): 521-42.

Huang, Yunong, Linlin Zhou, and Kenan Wei (2011). "5.12 Wenchuan Earthquake Recovery Government Policies and Non-Governmental Organizations' Participation”, Asia Pacific Journal of Social Work and Development 21(2): 77-91.

Jacoby, Tim. 2008. “The Role of the State in the Turkish Earthquake of 1999,'Journal of International Development 20(3): 297-310.

Kates, R.W., C.E. Colten, S. Laska, and S.P. Leatherman. 2006. "Reconstruction of New Orleans after Hurricane Katrina: A Research Perspective," PNAS 103(40): 14653-14660.

Kochar, Anjini. 1999. " "Smoothing Consumption by Smoothing Income: Hours-of-Work Responses to Idiosyncratic Agricultural Shocks in Rural India," Review-of-Economics-and-Statistics 81(1): 50-61.

Morduch, Jonathan. 1995 "Income Smoothing and Consumption Smoothing," Journal of Economic Perspectives 9: 103-114.

Park, Albert, and Sangui Wang. 2010. “Community Development and Poverty Alleviation: An Evaluation of China's Poor Village Investment Program," Journal of Public Economics, 94(9-10): 790-799.

Sawada, Y. (2007), "The Impact of Natural and Manmade Disasters on Household Welfare," Agricultural Economics 37 (s1), 59-73.

Sawada, Yasuyuki and Satoshi Shimizutani (2008) "How Do People Cope With a Natural Disaster? Evidence from the Great Hanshin-Awaji Earthquake," Journal of Money, Credit, and Banking 40 (2-3), 463-488. 
Sawada, Yasuyuki and Satoshi Shimizutani (2007). "Consumption Insurance against Natural Disasters: Evidence from the Great Hanshin-Awaji (Kobe) Earthquake," Applied Economics Letters 14 (4) March 2007, pages 303 - 306.

Shi, Peijun, Lianyou Liu, Jing'ai Wang, Wei Xu, Weihua Fang, Ming Wang (2012). "Experience, Lessons and Recommendation of China's Response to the Wenchuan Earthquake Disaster", in Integrated Risk Governance, IHDP-Integrated Risk Governance Project Series 2013, pp. 71-88.

Waugh, William L. 2006. "Economic Development and Reconstruction on the Gulf after Katrina," Economic Development Quarterly 20(3): 211-18.

World Bank. 2008. Aceh Poverty Assessment 2008: The Impact of the Conflict, the Tsunami and Reconstruction on Poverty in Aceh, (Washington, D.C.: The World Bank). 
Figure 1. Wenchuan Earthquake damage zones

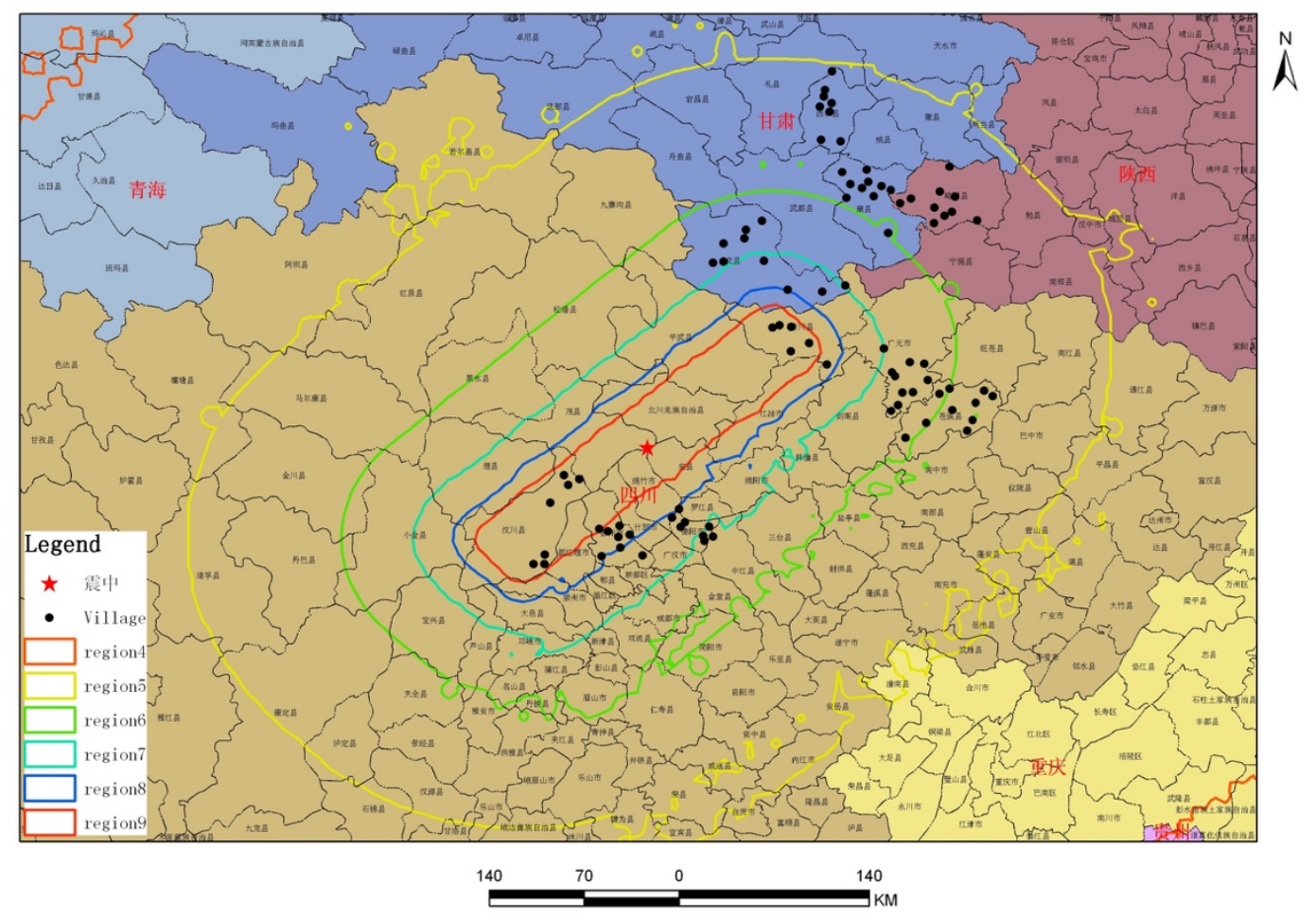


Figure 2: Share of public transfers (\%) by pre-transfer income per capita decile and asset loss decile, 2008

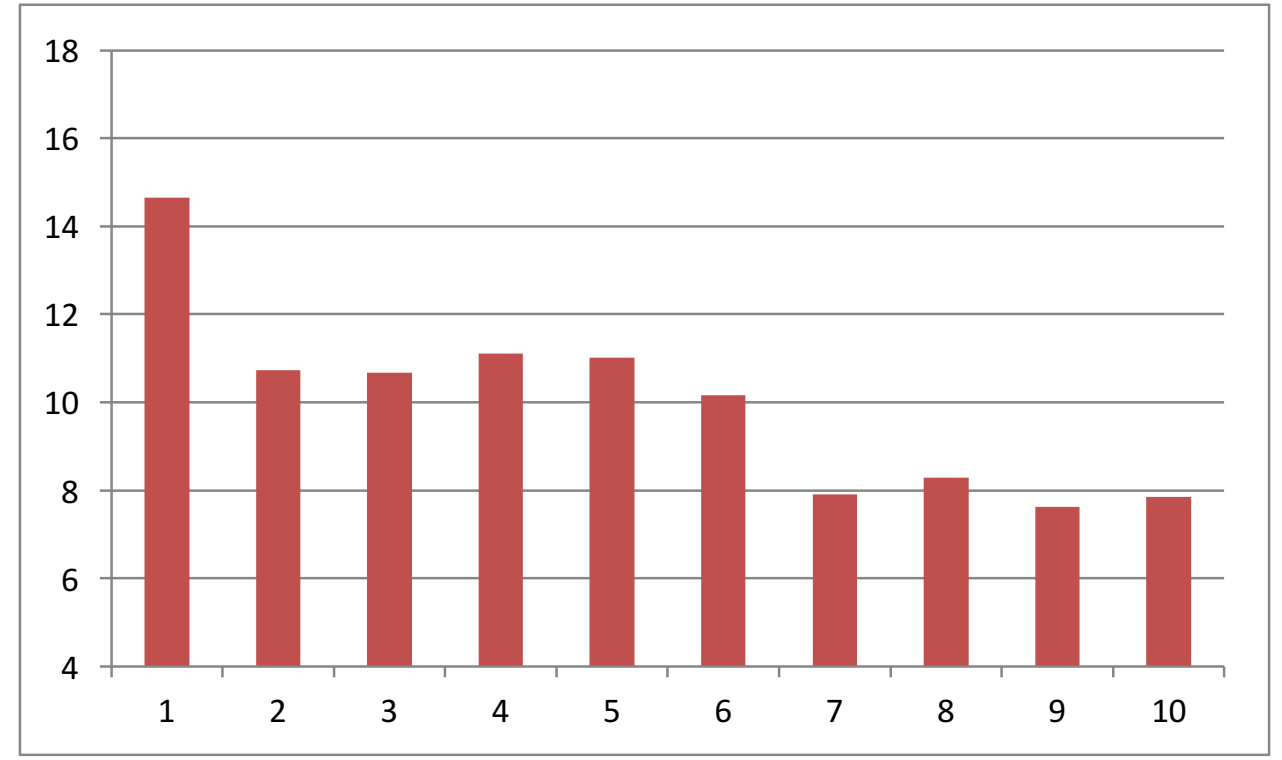

Panel A: Pre-transfer income per capita decile

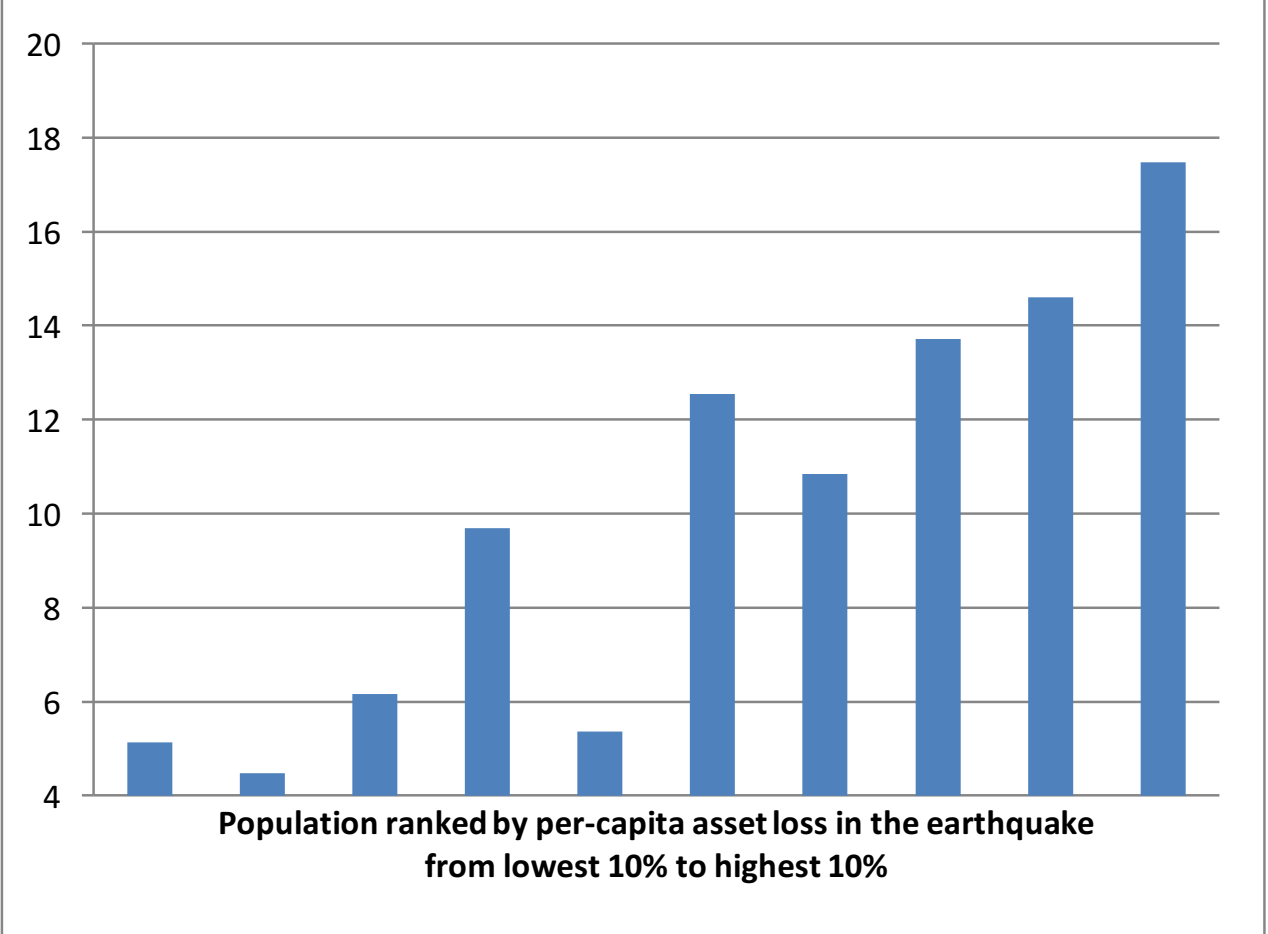

Panel B: Asset loss per capita decile 
Table 1: Property damage and losses

\begin{tabular}{lccc}
\hline & All & $\begin{array}{c}\text { Seriously } \\
\text { affected areas }\end{array}$ & $\begin{array}{c}\text { Less affected } \\
\text { areas. }\end{array}$ \\
\hline Land lost due to earthquake (mu & 0.09 & 0.21 & 0.04 \\
per capita) & $(0.27)$ & $(0.44)$ & $(0.13)$ \\
Proportion of land lost (\%) & 9.0 & 20.8 & 3.9 \\
Lost any land (\%) & $(19.2)$ & $(27.0)$ & $(11.2)$ \\
& 22.2 & 38.1 & 15.4 \\
House collapsed or seriously & $(41.6)$ & $(48.6)$ & $(36.1)$ \\
damaged (\%) & 46.4 & 71.7 & 35.5 \\
Housing value lost (yuan per & $(49.9)$ & $(45.1)$ & $(47.9)$ \\
capita) & 4096 & 8737 & 2187 \\
Lost any housing (\%) & $(9653)$ & $(14988)$ & $(5165)$ \\
& 97.6 & 98.8 & 97.1 \\
Value of non-housing assets lost & $(15.4)$ & $(11.0)$ & $(16.9)$ \\
(yuan per capita) & 396 & 1143 & 89 \\
Lost any non-housing assets (\%) & $(1551)$ & $(2590)$ & $(560)$ \\
& 38.5 & 79.1 & 21.1 \\
Share of pre-disaster wealth & $(48.7)$ & $(40.7)$ & $(40.8)$ \\
(housing and other assets) lost & 42.5 & 62.0 & 26.6 \\
lost(\%) & $(41.3)$ & $(39.6)$ & $(35.5)$ \\
Any damage to land, housing, or & 98.1 & 99.8 & 97.4 \\
other assets (\%) & $(13.5)$ & $(4.7)$ & $(15.8)$ \\
No. of obs. & & & \\
\hline Notes proportons weighted by base & 3000 & 900 & 2100 \\
\hline
\end{tabular}

Notes: proportions weighted by base values. 
Table 2: Income changes

\begin{tabular}{|c|c|c|c|c|c|c|c|c|c|c|c|c|}
\hline & \multicolumn{4}{|c|}{ All } & \multicolumn{4}{|c|}{ Seriously affected areas } & \multicolumn{4}{|c|}{ Less affected areas } \\
\hline & 2007 & 2008 & change & $\% \Delta$ & 2007 & 2008 & change & $\% \Delta$ & 2007 & 2008 & change & $\% \Delta$ \\
\hline $\begin{array}{l}\text { Pre-transfer income per } \\
\text { capita (yuan) }\end{array}$ & $\begin{array}{c}2926 \\
(4112)\end{array}$ & $\begin{array}{c}2332 \\
(3099)\end{array}$ & -594 & -20.3 & $\begin{array}{c}3005 \\
(3545)\end{array}$ & $\begin{array}{c}1921 \\
(3518)\end{array}$ & -1084 & -36.1 & $\begin{array}{c}2894 \\
(4325)\end{array}$ & $\begin{array}{c}2501 \\
(2891)\end{array}$ & -393 & -13.6 \\
\hline Any gov. transfers $\quad(\%)$ & $\begin{array}{c}87.3 \\
(33.3)\end{array}$ & $\begin{array}{c}97.8 \\
(14.6)\end{array}$ & 10.5 & & $\begin{array}{c}84.8 \\
(35.9)\end{array}$ & $\begin{array}{c}98.8 \\
(11.0)\end{array}$ & 14 & & $\begin{array}{c}88.4 \\
(32.0)\end{array}$ & $\begin{array}{c}97.4 \\
(15.8)\end{array}$ & 9 & \\
\hline Any private transfers $(\%)$ & $\begin{array}{c}12.5 \\
(33.0)\end{array}$ & $\begin{array}{c}17.2 \\
(37.8)\end{array}$ & 4.7 & & $\begin{array}{c}11.6 \\
(32.0)\end{array}$ & $\begin{array}{c}20.0 \\
(40.0)\end{array}$ & 8.4 & & $\begin{array}{c}12.9 \\
(33.5)\end{array}$ & $\begin{array}{c}16.0 \\
(36.7)\end{array}$ & 3.1 & \\
\hline $\begin{array}{l}\text { Other transfers per capita } \\
\text { (yuan) }\end{array}$ & 0 & $\begin{array}{c}16 \\
(146)\end{array}$ & 16 & - & 0 & $\begin{array}{c}39 \\
(244)\end{array}$ & 39 & - & 0 & $\begin{array}{c}6 \\
(73)\end{array}$ & 6 & - \\
\hline Any other transfers $(\%)$ & 0 & $\begin{array}{c}9.1 \\
(28.8)\end{array}$ & 9.1 & & 0 & $\begin{array}{c}13.1 \\
(33.8)\end{array}$ & 13.1 & & 0 & $\begin{array}{c}7.4 \\
(26.2)\end{array}$ & 7.4 & \\
\hline No. of obs. & & 3000 & & & & 900 & & & & 2100 & & \\
\hline
\end{tabular}


Table 3: Poverty headcount rates

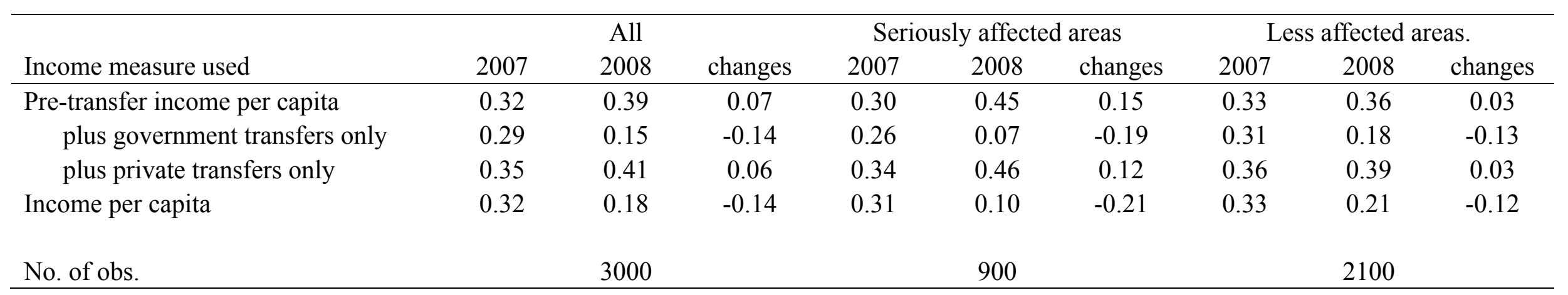


Table 4: Borrowing

\begin{tabular}{lccc}
\hline & All & $\begin{array}{c}\text { Seriously } \\
\text { affected areas }\end{array}$ & $\begin{array}{c}\text { Less } \\
\text { affected areas. }\end{array}$ \\
\hline New borrowing in 2007 & 881 & 1027 & 821 \\
& $(2889)$ & $(2780)$ & $(2931)$ \\
\% who have positive new borrowing & 33.0 & 31.2 & 33.8 \\
& $(47.0)$ & $(46.4)$ & $(47.3)$ \\
New borrowing in 2008 & 1590 & 1465 & 1641 \\
& $(4002)$ & $(4394)$ & $(3829)$ \\
\% who have positive new borrowing & 40.2 & 33.2 & 43.1 \\
& $(49.0)$ & $(47.1)$ & $(49.5)$ \\
Of which: borrowing after the earthquake & 1363 & 1290 & 1393 \\
& $(3672)$ & $(4205)$ & $(3428)$ \\
Outstanding loans at the end of 2008 & 2565 & 2669 & 2522 \\
& $(5260)$ & $(5548)$ & $(5137)$ \\
Credit limit at time of earthquake & 3522 & 3663 & 3464 \\
& $(6384)$ & $(7060)$ & $(6084)$ \\
No. of obs. & & & 2100 \\
\hline Notes: Credit limit equals self-reported ability to borrow additional funds at time of survey plus new borrowing \\
after the earthquake. All numbers are per capita.
\end{tabular}


Table 5: Labor supply and wages

\begin{tabular}{|c|c|c|c|c|c|c|c|c|c|c|c|c|}
\hline & \multicolumn{4}{|c|}{ All } & \multicolumn{4}{|c|}{ Seriously affected areas } & \multicolumn{4}{|c|}{ Less affected areas. } \\
\hline & 2007 & 2008 & change & $\% \Delta$ & 2007 & 2008 & change & $\% \Delta$ & 2007 & 2008 & change & $\% \Delta$ \\
\hline $\begin{array}{l}\text { Number of household members in } \\
\text { wage employment }\end{array}$ & $\begin{array}{c}0.95 \\
(0.90)\end{array}$ & $\begin{array}{c}0.99 \\
(0.92)\end{array}$ & 0.04 & 4.2 & $\begin{array}{c}0.93 \\
(0.92)\end{array}$ & $\begin{array}{c}0.97 \\
(0.94)\end{array}$ & 0.04 & 4.3 & $\begin{array}{c}0.96 \\
(0.90)\end{array}$ & $\begin{array}{c}1.0 \\
(0.91)\end{array}$ & 0.04 & 4.2 \\
\hline Months worked per worker & $\begin{array}{c}9.13 \\
(3.08)\end{array}$ & $\begin{array}{c}7.73 \\
(3.44)\end{array}$ & -1.4 & -15.3 & $\begin{array}{l}9.16 \\
(3.10)\end{array}$ & $\begin{array}{c}7.26 \\
(3.50)\end{array}$ & -1.9 & -20.7 & $\begin{array}{c}9.12 \\
(3.07)\end{array}$ & $\begin{array}{c}7.93 \\
(3.40)\end{array}$ & -1.19 & -13.1 \\
\hline $\begin{array}{l}\text { Monthly wage (weighted by months } \\
\text { worked) }\end{array}$ & $\begin{array}{c}943 \\
(746)\end{array}$ & $\begin{array}{c}891 \\
(620)\end{array}$ & -52 & -5.5 & $\begin{array}{c}907 \\
(676)\end{array}$ & $\begin{array}{c}877 \\
(737)\end{array}$ & -30 & -3.3 & $\begin{array}{c}958 \\
(774)\end{array}$ & $\begin{array}{c}896 \\
(569)\end{array}$ & -62 & -6.5 \\
\hline $\begin{array}{l}\text { Monthly wage local wage } \\
\text { employment }\end{array}$ & $\begin{array}{c}879 \\
(877)\end{array}$ & $\begin{array}{c}830 \\
(659)\end{array}$ & -49 & -5.6 & $\begin{array}{c}842 \\
(813)\end{array}$ & $\begin{array}{c}794 \\
(728)\end{array}$ & -48 & -5.7 & $\begin{array}{c}912 \\
(930)\end{array}$ & $\begin{array}{c}857 \\
(603)\end{array}$ & -55 & -6.0 \\
\hline Monthly wage for migrants & $\begin{array}{c}980 \\
(644)\end{array}$ & $\begin{array}{c}944 \\
(610)\end{array}$ & -36 & -3.77 & $\begin{array}{l}978 \\
(688)\end{array}$ & $\begin{array}{l}958 \\
(754)\end{array}$ & -20 & -2.0 & $\begin{array}{c}981 \\
(628)\end{array}$ & $\begin{array}{c}939 \\
(557)\end{array}$ & -42 & -4.3 \\
\hline Wage income per pc & $\begin{array}{c}2041 \\
(2848)\end{array}$ & $\begin{array}{c}1701 \\
(2287)\end{array}$ & -340 & -16.7 & $\begin{array}{c}1997 \\
(2746)\end{array}$ & $\begin{array}{c}1584 \\
(2252)\end{array}$ & -413 & -20.7 & $\begin{array}{c}2059 \\
(2889)\end{array}$ & $\begin{array}{c}1749 \\
(2300)\end{array}$ & -310 & -15.1 \\
\hline $\begin{array}{l}\text { Wage share of total household income } \\
\text { (not weighted by household income) } \\
\text { Type of work }(\%)\end{array}$ & $\begin{array}{c}51.1 \\
(135.1)\end{array}$ & $\begin{array}{c}39.6 \\
(97.3)\end{array}$ & -11.5 & - & $\begin{array}{c}47.0 \\
(135.8)\end{array}$ & $\begin{array}{c}32.7 \\
(63.3)\end{array}$ & -14.3 & - & $\begin{array}{c}52.9 \\
(134.8)\end{array}$ & $\begin{array}{c}42.6 \\
(108.5)\end{array}$ & -10.3 & - \\
\hline Local wage employment & $\begin{array}{c}24.5 \\
(41.2)\end{array}$ & $\begin{array}{c}23.7 \\
(40.4)\end{array}$ & -0.8 & - & $\begin{array}{c}35.1 \\
(45.9)\end{array}$ & $\begin{array}{c}33.7 \\
(44.9)\end{array}$ & -1.4 & - & $\begin{array}{c}20.1 \\
(38.3)\end{array}$ & $\begin{array}{c}19.6 \\
(37.7)\end{array}$ & -0.5 & - \\
\hline Migrate & $\begin{array}{c}69.4 \\
(44.0)\end{array}$ & $\begin{array}{c}69.9 \\
(43.4)\end{array}$ & 0.5 & - & $\begin{array}{c}59.4 \\
(47.1)\end{array}$ & $\begin{array}{c}59.6 \\
(46.3)\end{array}$ & 0.3 & - & $\begin{array}{c}73.7 \\
(42.0)\end{array}$ & $\begin{array}{c}74.3 \\
(41.4)\end{array}$ & 0.6 & - \\
\hline Other & $\begin{array}{c}6.0 \\
(22.2)\end{array}$ & $\begin{array}{c}6.3 \\
(22.4)\end{array}$ & 0.3 & - & $\begin{array}{c}5.6 \\
(21.3)\end{array}$ & $\begin{array}{c}6.7 \\
(22.7)\end{array}$ & 1.2 & - & $\begin{array}{c}6.2 \\
(22.6)\end{array}$ & $\begin{array}{c}6.2 \\
(22.2)\end{array}$ & -0.1 & - \\
\hline
\end{tabular}


Table 6: Impact of earthquake on income per capita, pre-transfer income per capita, and wage labor hours

\begin{tabular}{|c|c|c|c|c|c|c|}
\hline & $\begin{array}{l}\Delta \text { income } \\
\text { p.c. }\end{array}$ & $\begin{array}{l}\Delta \text { income } \\
\text { p.c. }\end{array}$ & $\begin{array}{c}\Delta \text { pre- } \\
\text { transfer } \\
\text { income p.c. }\end{array}$ & $\begin{array}{c}\Delta \text { pre- } \\
\text { transfer } \\
\text { income p.c. }\end{array}$ & $\begin{array}{l}\Delta \text { labor } \\
\text { months }\end{array}$ & $\begin{array}{l}\Delta \text { labor } \\
\text { months }\end{array}$ \\
\hline \multicolumn{7}{|l|}{ Ordinary Least Squares } \\
\hline \multirow[t]{2}{*}{ Ln (asset loss p.c.) } & -90.575 & 78.092 & -174.465 & -146.601 & -0.182 & -0.181 \\
\hline & $(92.426)$ & $(69.023)$ & $(47.122)^{* *}$ & $(50.326)^{* *}$ & $(0.104)$ & $(0.099)$ \\
\hline \multicolumn{7}{|c|}{ Instrumental Variables (2SLS) } \\
\hline \multirow{2}{*}{ Ln (asset loss p.c.) } & & 1346.906 & & 11.123 & & 0.009 \\
\hline & & $(450.575)^{* *}$ & & $(218.306)$ & & $(0.334)$ \\
\hline Location fixed effects & county & province & county & province & county & province \\
\hline$N$ & 2,985 & 2,985 & 2,985 & 2,985 & 2,985 & 2,985 \\
\hline
\end{tabular}

Notes: Standard errors in parentheses, $* \mathrm{p}<0.05, * * \mathrm{p}<0.01, * * * \mathrm{p}<0.001$. Variables included in these regressions include: household head age (2007), household size (2007), household labor (2007), labor share-middle (2007), labor share-high (2007), cultivated land p.c. (2007), In(housing value p.c.) (2007), $\ln$ (other assets pc.) (2007), no labor dummy, $\ln$ (distance to national road), $\ln$ (distance to river), ln (distance to rail station), mountainous, and hilly. Specifications without county fixed effects also include county population (2007), county GDP p.c. (2007), and county revenue p.c. (2007). Full results for OLS regressions are reported in Table A2, and first-stage regression results for the IV specification are reported in Table A4. 
Table 7: Response of government transfers, private transfers, and borrowing to earthquake damage and income loss

\begin{tabular}{|l|c|c|c|c|c|c|}
\hline & $\begin{array}{c}\Delta \text { govt } \\
\text { transfers } \\
\text { p.c. }\end{array}$ & $\begin{array}{c}\Delta \text { govt } \\
\text { transfers } \\
\text { p.c. }\end{array}$ & $\begin{array}{c}\Delta \text { private } \\
\text { transfers } \\
\text { p.c. }\end{array}$ & $\begin{array}{c}\Delta \text { private } \\
\text { transfers } \\
\text { p.c. }\end{array}$ & $\begin{array}{c}\text { new } \\
\text { borrowing } \\
\text { p.c. }\end{array}$ & $\begin{array}{c}\text { new } \\
\text { borrowing } \\
\text { p.c. }\end{array}$ \\
\hline Ordinary Least Squares & & & & & & \\
\hline Ln (asset loss p.c.) & 169.241 & 241.5 & -87.957 & -19.551 & 540.728 & 401.686 \\
\hline & $(27.835)^{* *}$ & $(27.203)^{* *}$ & $(68.173)$ & $(34.306)$ & $(109.010)^{* *}$ & $(99.185)^{* *}$ \\
\hline Instrumental Variables (2SLS) & & & & & & \\
\hline \multicolumn{1}{|c|}{ Ln (asset loss p.c.) } & & 889.074 & & 433.825 & & -552.577 \\
\hline & & $(119.346)^{* *}$ & & $(346.952)$ & & $(415.789)$ \\
\hline Location fixed effects & county & province & county & province & county & province \\
\hline$N$ & 2,985 & 2,985 & 2,985 & 2,985 & 2,985 & 2,985 \\
\hline
\end{tabular}

Notes: Standard errors in parentheses, $* \mathrm{p}<0.05, * * \mathrm{p}<0.01, * * * \mathrm{p}<0.001$. Variables included in these regressions include: household head age (2007), household size (2007), household labor (2007), labor share-middle (2007), labor share-high (2007), cultivated land p.c. (2007), ln(housing value p.c.) (2007),

$\ln$ (other assets pc.) (2007), no labor dummy, $\ln$ (distance to national road), $\ln$ (distance to river), ln (distance to rail station), mountainous, and hilly. Specifications without county fixed effects also include county population (2007), county GDP p.c. (2007), and county revenue p.c. (2007). Full results for OLS regressions are reported in Table A3, and first-stage regression results for the IV specification are reported in Table A4. 
Table A1: Descriptive Statistics

\begin{tabular}{|c|c|c|c|}
\hline Covariates & Unit & No. of Obs. & Mean \\
\hline$\Delta$ incpc & yuan per capita & 2985 & $\begin{array}{c}635.6 \\
(4365.5)\end{array}$ \\
\hline$\Delta$ pre-tran incpc & yuan per capita & 2985 & $\begin{array}{c}-561.8 \\
(3472.6)\end{array}$ \\
\hline$\Delta$ labor months & month & 2985 & $\begin{array}{l}-0.98 \\
(5.77)\end{array}$ \\
\hline$\Delta$ gov trans pc & yuan per capita & 2985 & $\begin{array}{c}977.3 \\
(1446.0)\end{array}$ \\
\hline$\Delta$ priv trans $\mathrm{pc}$ & yuan per capita & 2985 & $\begin{array}{c}202.2 \\
(2225.6)\end{array}$ \\
\hline new borrow pc & yuan per capita & 2985 & $\begin{array}{c}1482.6 \\
(4168.1)\end{array}$ \\
\hline land loss pc & mu per capita & 2985 & $\begin{array}{c}0.09 \\
(0.31)\end{array}$ \\
\hline house loss & 1000 yuan per capita & 2985 & $\begin{array}{c}4.50 \\
(11.04)\end{array}$ \\
\hline asset loss (1000 yuan pc) & 1000 yuan per capita & 2985 & $\begin{array}{c}0.40 \\
(1.58)\end{array}$ \\
\hline killed/injured & No. of persons & 2985 & $\begin{array}{c}0.24 \\
(0.79)\end{array}$ \\
\hline hh head age 2007 & year & 2985 & $\begin{array}{c}48.6 \\
(12.3)\end{array}$ \\
\hline household size 2007 & No. of persons & 2985 & $\begin{array}{c}4.06 \\
(1.51)\end{array}$ \\
\hline labor 2007 & No. of persons & 2985 & $\begin{array}{c}2.15 \\
(1.14)\end{array}$ \\
\hline lab share middle 2007 & - & 2985 & $\begin{array}{c}0.22 \\
(0.31)\end{array}$ \\
\hline lab_share high 2007 & - & 2985 & $\begin{array}{c}0.02 \\
(0.10)\end{array}$ \\
\hline land pc 2007 & mu per capita & 2985 & $\begin{array}{c}1.05 \\
(0.91)\end{array}$ \\
\hline house value pc 2007 & 1000 yuan per capita & 2985 & $\begin{array}{c}9.19 \\
(14.91)\end{array}$ \\
\hline asset value pc 2007 & 1000 yuan per capita & 2985 & $\begin{array}{c}2.36 \\
(5.20)\end{array}$ \\
\hline county population & 10,000 person & 2985 & $\begin{array}{c}38.6 \\
(24.1)\end{array}$ \\
\hline county GDP pc & yuan per capita & 2985 & $\begin{array}{c}6129.9 \\
(5908.2)\end{array}$ \\
\hline county rev pc & yuan per capita & 2985 & $\begin{array}{c}258.4 \\
(285.5) \\
\end{array}$ \\
\hline
\end{tabular}


Table A2: Determinants of changes in Income Per Capita, Pre-transfer Income Per Capita, and Labor Months (OLS)

\begin{tabular}{|c|c|c|c|c|c|c|}
\hline & $\Delta$ income p.c. & $\Delta$ income p.c. & $\begin{array}{l}\Delta \text { pre-transfer } \\
\text { income p.c. }\end{array}$ & $\begin{array}{l}\Delta \text { pre-transfer } \\
\text { income p.c. }\end{array}$ & $\Delta$ labor months & $\Delta$ labor months \\
\hline \multirow[t]{2}{*}{ Ln (asset loss p.c.) } & -90.575 & 78.092 & -174.465 & -146.601 & -0.182 & -0.181 \\
\hline & $(92.426)$ & $(69.023)$ & $(47.122)^{* *}$ & $(50.326)^{* *}$ & $(0.104)$ & $(0.099)$ \\
\hline \multirow[t]{2}{*}{ Household head age (2007) } & 5.157 & 6.171 & 6.472 & 6.372 & 0.013 & 0.011 \\
\hline & (7.372) & $(7.441)$ & $(6.273)$ & $(6.181)$ & $(0.009)$ & $(0.009)$ \\
\hline \multirow[t]{2}{*}{ Household size (2007) } & -182.713 & -200.116 & -24.810 & -20.512 & -0.156 & -0.153 \\
\hline & $(100.358)$ & $(106.163)$ & $(58.381)$ & $(56.674)$ & $(0.100)$ & $(0.099)$ \\
\hline \multirow[t]{2}{*}{ Household labor (2007) } & 12.738 & 38.179 & 1.201 & -3.592 & 0.010 & 0.013 \\
\hline & $(112.523)$ & $(115.886)$ & $(96.731)$ & $(93.730)$ & $(0.177)$ & $(0.171)$ \\
\hline \multirow[t]{2}{*}{ Labor share-middle (2007) } & 284.556 & 381.752 & 205.019 & 228.941 & -0.333 & -0.322 \\
\hline & $(253.987)$ & $(280.560)$ & $(229.580)$ & $(231.229)$ & $(0.411)$ & $(0.409)$ \\
\hline \multirow[t]{2}{*}{ Labor share-high (2007) } & $-1,240.240$ & $-1,200.815$ & -467.750 & -473.230 & 2.178 & 2.173 \\
\hline & $(1,362.632)$ & $(1,366.974)$ & $(1,247.222)$ & $(1,248.133)$ & $(1.139)$ & $(1.144)$ \\
\hline \multirow[t]{2}{*}{ Cultivate land p.c. (2007) } & -215.093 & -215.230 & -81.822 & -75.200 & 0.111 & 0.130 \\
\hline & $(140.295)$ & $(147.225)$ & (93.408) & $(92.073)$ & $(0.111)$ & $(0.114)$ \\
\hline \multirow[t]{2}{*}{ Ln (house value p.c.) (2007) } & -18.050 & 48.229 & 67.125 & 82.401 & 0.104 & 0.118 \\
\hline & $(84.277)$ & $(95.752)$ & $(60.071)$ & $(57.378)$ & $(0.099)$ & $(0.098)$ \\
\hline \multirow[t]{2}{*}{ Ln (other asset pc.) (2007) } & -160.914 & -213.623 & -368.306 & -370.965 & -0.037 & -0.042 \\
\hline & $(208.438)$ & $(207.956)$ & $(146.139)^{*}$ & $(147.791)^{*}$ & $(0.119)$ & $(0.116)$ \\
\hline \multirow[t]{2}{*}{ No labor } & 950.385 & 966.429 & 320.397 & 323.576 & -0.001 & 0.037 \\
\hline & $(493.215)$ & $(509.829)$ & $(250.903)$ & $(244.683)$ & $(0.479)$ & $(0.472)$ \\
\hline \multirow[t]{2}{*}{ Ln (distance to national road) } & 13.142 & 50.060 & -2.155 & -11.606 & 0.088 & 0.253 \\
\hline & $(139.132)$ & $(119.281)$ & $(91.632)$ & $(65.920)$ & $(0.103)$ & $(0.100)^{*}$ \\
\hline \multirow[t]{2}{*}{ Ln (distance to river) } & 23.426 & 66.499 & -5.822 & -10.525 & 0.080 & 0.083 \\
\hline & $(133.779)$ & $(156.723)$ & $(55.472)$ & $(59.113)$ & $(0.082)$ & $(0.086)$ \\
\hline \multirow[t]{2}{*}{ Ln (distance to rail station) } & -410.909 & -425.373 & -208.432 & -210.821 & -0.218 & -0.290 \\
\hline & $(272.464)$ & $(280.761)$ & $(147.703)$ & $(135.578)$ & $(0.170)$ & $(0.168)$ \\
\hline \multirow[t]{2}{*}{ Mountainous } & 457.007 & 231.916 & -243.996 & -529.124 & -0.176 & -0.198 \\
\hline & $(553.888)$ & $(581.306)$ & $(317.301)$ & $(283.659)$ & $(0.658)$ & $(0.518)$ \\
\hline \multirow[t]{2}{*}{ Hilly } & -183.744 & -562.469 & -159.386 & -220.040 & 0.025 & -0.047 \\
\hline & $(404.045)$ & $(448.295)$ & $(262.650)$ & $(259.986)$ & $(0.502)$ & $(0.488)$ \\
\hline \multirow[t]{2}{*}{ County population (2007) } & & -9.369 & & 5.095 & & 0.014 \\
\hline & & (7.679) & & $(3.873)$ & & $(0.006)^{*}$ \\
\hline \multirow[t]{2}{*}{ County GDP p.c. (2007) } & & -9.330 & & 9.186 & & 0.022 \\
\hline & & (11.088) & & $(4.233)^{*}$ & & $(0.007)^{* *}$ \\
\hline
\end{tabular}




\begin{tabular}{|c|c|c|c|c|c|c|}
\hline County revenue p.c. (2007) & & $\begin{array}{r}0.020 \\
(0.100)\end{array}$ & & $\begin{array}{r}-0.023 \\
(0.059)\end{array}$ & & $\begin{array}{r}0.000 \\
(0.000)\end{array}$ \\
\hline \multirow[t]{2}{*}{ Constant } & $3,023.790$ & $1,398.539$ & 747.374 & 166.683 & 0.107 & -1.645 \\
\hline & $(1,067.956)^{* *}$ & $(777.387)$ & $(607.941)$ & $(543.796)$ & $(1.085)$ & (1.198) \\
\hline Location fixed effects & county & province & county & province & county & province \\
\hline$R^{2}$ & 0.05 & 0.02 & 0.05 & 0.05 & 0.04 & 0.03 \\
\hline$N$ & 2,985 & 2,985 & 2,985 & 2,985 & 2,985 & 2,985 \\
\hline
\end{tabular}


Table A3. Determinants of Government Transfers, Private Transfers, and New Borrowing (OLS) 


\begin{tabular}{|c|c|c|c|c|c|c|}
\hline & p.c. & p.c. & p.c. & p.c. & p.c. & p.c. \\
\hline \multirow[t]{2}{*}{ Ln (asset loss p.c.) } & 169.241 & 241.500 & -87.957 & -19.551 & 540.728 & 401.686 \\
\hline & $(27.835)^{* *}$ & $(27.203)^{* *}$ & $(68.173)$ & $(34.306)$ & $(109.010)^{* *}$ & $(99.185)^{* *}$ \\
\hline \multirow[t]{2}{*}{ Household head age (2007) } & -0.582 & 0.651 & -0.458 & -0.541 & -11.756 & -10.748 \\
\hline & $(2.003)$ & $(2.045)$ & $(2.329)$ & $(2.250)$ & $(6.520)$ & $(6.322)$ \\
\hline \multirow[t]{2}{*}{ Household size (2007) } & -83.796 & -100.420 & -72.997 & -77.502 & -239.871 & -206.790 \\
\hline & $(21.112)^{* *}$ & $(21.344)^{* *}$ & $(74.972)$ & $(80.682)$ & $(62.465)^{* *}$ & $(62.363)^{* *}$ \\
\hline \multirow[t]{2}{*}{ Household labor (2007) } & -11.325 & 6.912 & 25.297 & 36.451 & 142.310 & 100.530 \\
\hline & $(19.518)$ & $(21.006)$ & $(52.656)$ & $(58.580)$ & $(78.676)$ & $(79.940)$ \\
\hline \multirow[t]{2}{*}{ Labor share-middle (2007) } & 5.518 & 35.054 & 84.615 & 128.631 & 773.545 & 702.960 \\
\hline & $(73.972)$ & $(76.697)$ & $(94.740)$ & $(118.289)$ & $(308.167)^{*}$ & $(315.297)^{*}$ \\
\hline \multirow[t]{2}{*}{ Labor share-high (2007) } & -299.433 & -270.751 & -454.392 & -439.012 & -806.403 & -853.403 \\
\hline & $(179.903)$ & $(193.325)$ & $(354.951)$ & $(349.742)$ & $(491.780)$ & $(527.629)$ \\
\hline \multirow[t]{2}{*}{ Cultivate land p.c. (2007) } & 44.855 & 35.272 & -187.431 & -184.712 & -136.519 & -156.132 \\
\hline & $(37.872)$ & $(39.872)$ & $(98.097)$ & $(100.422)$ & $(113.892)$ & $(127.428)$ \\
\hline \multirow[t]{2}{*}{ Ln (house value p.c.) (2007) } & -112.226 & -93.463 & 31.736 & 63.880 & -152.935 & -210.023 \\
\hline & $(31.299)^{* *}$ & $(33.454)^{* *}$ & $(53.013)$ & $(70.574)$ & $(113.421)$ & $(113.416)$ \\
\hline \multirow[t]{2}{*}{ Ln (other asset pc.) } & 31.714 & 7.559 & 177.968 & 152.662 & 38.122 & 86.440 \\
\hline & $(22.220)$ & $(24.212)$ & $(129.276)$ & $(121.777)$ & $(75.447)$ & $(81.779)$ \\
\hline \multirow[t]{2}{*}{ No labor } & 20.359 & 21.826 & 591.141 & 601.177 & -874.463 & -963.093 \\
\hline & $(98.398)$ & $(104.175)$ & $(351.332)$ & $(364.944)$ & $(324.171)^{* *}$ & $(332.333)^{* *}$ \\
\hline \multirow[t]{2}{*}{ Ln (distance to national road) } & 6.092 & -10.915 & 30.458 & 87.230 & 143.684 & -135.400 \\
\hline & $(39.352)$ & $(50.240)$ & $(88.095)$ & $(66.851)$ & $(161.614)$ & $(128.086)$ \\
\hline \multirow[t]{2}{*}{$\mathrm{Ln}$ (distance to river) } & -89.181 & -66.907 & 124.135 & 148.759 & 106.442 & 73.835 \\
\hline & $(52.052)$ & $(54.860)$ & $(115.223)$ & $(133.110)$ & $(101.199)$ & $(113.175)$ \\
\hline \multirow[t]{2}{*}{ Ln (distance to rail station) } & -56.437 & -55.135 & -152.326 & -162.934 & -337.944 & -169.058 \\
\hline & $(114.908)$ & $(115.243)$ & $(163.667)$ & $(174.611)$ & $(258.872)$ & $(208.140)$ \\
\hline \multirow[t]{2}{*}{ Mountainous } & 162.176 & 111.764 & 557.095 & 654.457 & -736.670 & -120.956 \\
\hline & $(267.495)$ & $(276.884)$ & $(357.684)$ & $(418.624)$ & $(620.523)$ & $(663.687)$ \\
\hline \multirow[t]{2}{*}{ Hilly } & -20.517 & -175.887 & -0.693 & -160.292 & -655.883 & -193.371 \\
\hline & $(248.152)$ & $(264.471)$ & $(131.031)$ & $(183.511)$ & $(572.180)$ & $(608.822)$ \\
\hline \multirow[t]{2}{*}{ County population (2007) } & & -6.337 & & -12.019 & & 0.608 \\
\hline & & $(2.734)^{*}$ & & $(9.327)$ & & $(7.561)$ \\
\hline \multirow[t]{2}{*}{ County GDP p.c. (2007) } & & 0.013 & & 0.033 & & -0.040 \\
\hline & & $(0.049)$ & & $(0.055)$ & & $(0.098)$ \\
\hline \multirow[t]{2}{*}{ County revenue p.c. (2007) } & & 0.935 & & -1.371 & & 1.236 \\
\hline & & $(0.972)$ & & $(1.506)$ & & (2.473) \\
\hline \multirow[t]{2}{*}{ Constant } & $1,728.149$ & $1,189.819$ & 463.789 & -37.871 & $2,507.020$ & $3,933.052$ \\
\hline & $(512.008)^{* *}$ & $(441.325)^{* *}$ & $(586.095)$ & $(358.293)$ & $(1,295.726)$ & $(1,199.963)^{* *}$ \\
\hline Location fixed effects & county & province & county & province & county & province \\
\hline$R^{2}$ & 0.23 & 0.19 & 0.08 & 0.04 & 0.06 & 0.04 \\
\hline$N$ & 2,985 & 2,985 & 2,985 & 2,985 & 2,985 & 2,985 \\
\hline
\end{tabular}


Table A4. First-stage regression results

\begin{tabular}{|c|c|}
\hline & $\begin{array}{l}\text { Ln(asset } \\
\text { value p.c.) }\end{array}$ \\
\hline Household head age (2007) & $\begin{array}{l}-0.002 \\
(0.002)\end{array}$ \\
\hline Household size (2007) & $\begin{array}{l}-0.086 \\
(0.020)^{* *}\end{array}$ \\
\hline Household labor (2007) & $\begin{array}{l}-0.013 \\
(0.026)\end{array}$ \\
\hline Labor share-middle (2007) & $\begin{array}{l}0.133 \\
(0.075)\end{array}$ \\
\hline Labor share-high (2007) & $\begin{array}{l}0.306 \\
(0.192)\end{array}$ \\
\hline Cultivate land p.c. (2007) & $\begin{array}{l}0.013 \\
(0.032)\end{array}$ \\
\hline Ln (house value p.c.) (2007) & $\begin{array}{l}0.547 \\
(0.036)^{* *}\end{array}$ \\
\hline Ln (other asset pc.) (2007) & $\begin{array}{l}0.049 \\
(0.029)\end{array}$ \\
\hline No labor & $\begin{array}{l}0.022 \\
(0.096)\end{array}$ \\
\hline Ln (distance to national road) & $\begin{array}{l}-0.064 \\
(0.057)\end{array}$ \\
\hline Ln (distance to river) & $\begin{array}{l}0.010 \\
(0.030)\end{array}$ \\
\hline Ln (distance to rail station) & $\begin{array}{l}0.005 \\
(0.069)\end{array}$ \\
\hline Mountainous & $\begin{array}{l}0.636 \\
(0.258)^{*}\end{array}$ \\
\hline Hilly & $\begin{array}{l}0.168 \\
(0.276)\end{array}$ \\
\hline County population (2007) & $\begin{array}{l}-0.003 \\
(0.003)\end{array}$ \\
\hline County GDP p.c. (2007) & $\begin{array}{l}-0.000 \\
(0.000)\end{array}$ \\
\hline County revenue p.c. (2007) & $\begin{array}{l}0.000 \\
(0.001)\end{array}$ \\
\hline Shaanxi Province & $\begin{array}{l}-0.283 \\
(0.318)\end{array}$ \\
\hline Gansu Province & $\begin{array}{l}0.091 \\
(0.166)\end{array}$ \\
\hline Earthquake region 6 & $\begin{array}{l}0.322 \\
(0.151)^{*}\end{array}$ \\
\hline Earthquake region 7 & $\begin{array}{l}1.049 \\
(0.280)^{* *}\end{array}$ \\
\hline Earthquake region 8 & $\begin{array}{l}1.291 \\
(0.167)^{* *}\end{array}$ \\
\hline Earthquake region 9 & $\begin{array}{l}1.602 \\
(0.223) * *\end{array}$ \\
\hline Constant & $\begin{array}{l}-0.790 \\
(0.433)\end{array}$ \\
\hline$R^{2}$ & 0.54 \\
\hline$N$ & 2,985 \\
\hline
\end{tabular}


the earthquake region dummy variables is 20.3 . 